
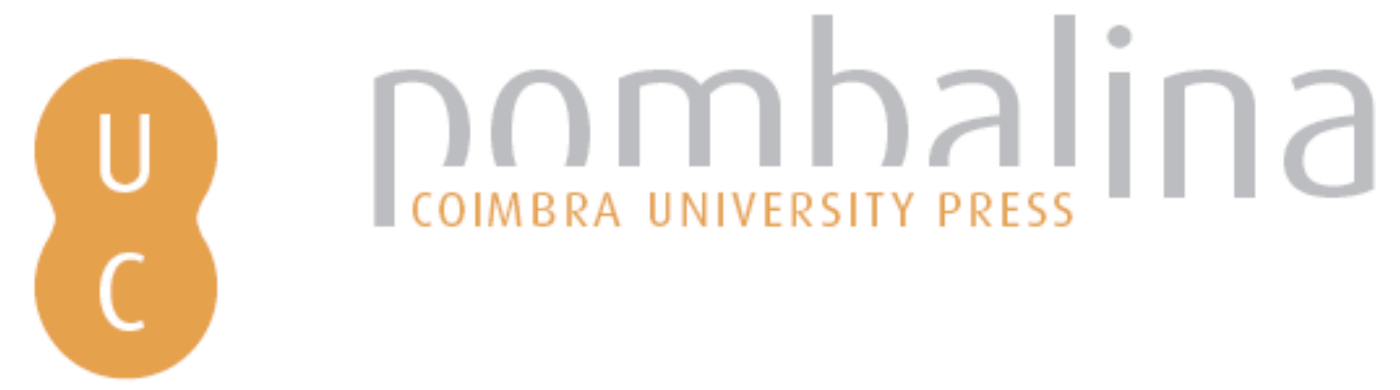

\title{
Characteristics and consequences of temporal orientation for psychological well- being: learning from the past, fearing the future and living for today
}

\author{
Autor(es): $\quad$ Jones, James M.; Leitner, Jordan B.; Marshall, Charlotte; Jing, Yiming; \\ Lee, Jeong Min
}

Publicado por: Imprensa da Universidade de Coimbra

URL persistente:

URI:http://hdl.handle.net/10316.2/38619

DOI:

DOI:http://dx.doi.org/10.14195/978-989-26-0775-7_15

Accessed : $\quad$ 26-Apr-2023 01:50:29

A navegação consulta e descarregamento dos títulos inseridos nas Bibliotecas Digitais UC Digitalis, UC Pombalina e UC Impactum, pressupõem a aceitação plena e sem reservas dos Termos e Condições de Uso destas Bibliotecas Digitais, disponíveis em https://digitalis.uc.pt/pt-pt/termos.

Conforme exposto nos referidos Termos e Condições de Uso, o descarregamento de títulos de acesso restrito requer uma licença válida de autorização devendo o utilizador aceder ao(s) documento(s) a partir de um endereço de IP da instituição detentora da supramencionada licença.

Ao utilizador é apenas permitido o descarregamento para uso pessoal, pelo que o emprego do(s) título(s) descarregado(s) para outro fim, designadamente comercial, carece de autorização do respetivo autor ou editor da obra.

Na medida em que todas as obras da UC Digitalis se encontram protegidas pelo Código do Direito de Autor e Direitos Conexos e demais legislação aplicável, toda a cópia, parcial ou total, deste documento, nos casos em que é legalmente admitida, deverá conter ou fazer-se acompanhar por este aviso.

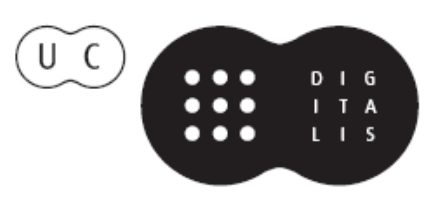




\section{INTERNATIONAL \\ STUDIES IN TIME \\ PERSPECTIVE}

MARIA PAULA PAIXÃO

JOSÉ TOMÁS DA SILVA

(COORD.)

VICTOR ORTUÑO

PEDRO CORDEIRO

(EDITORS)

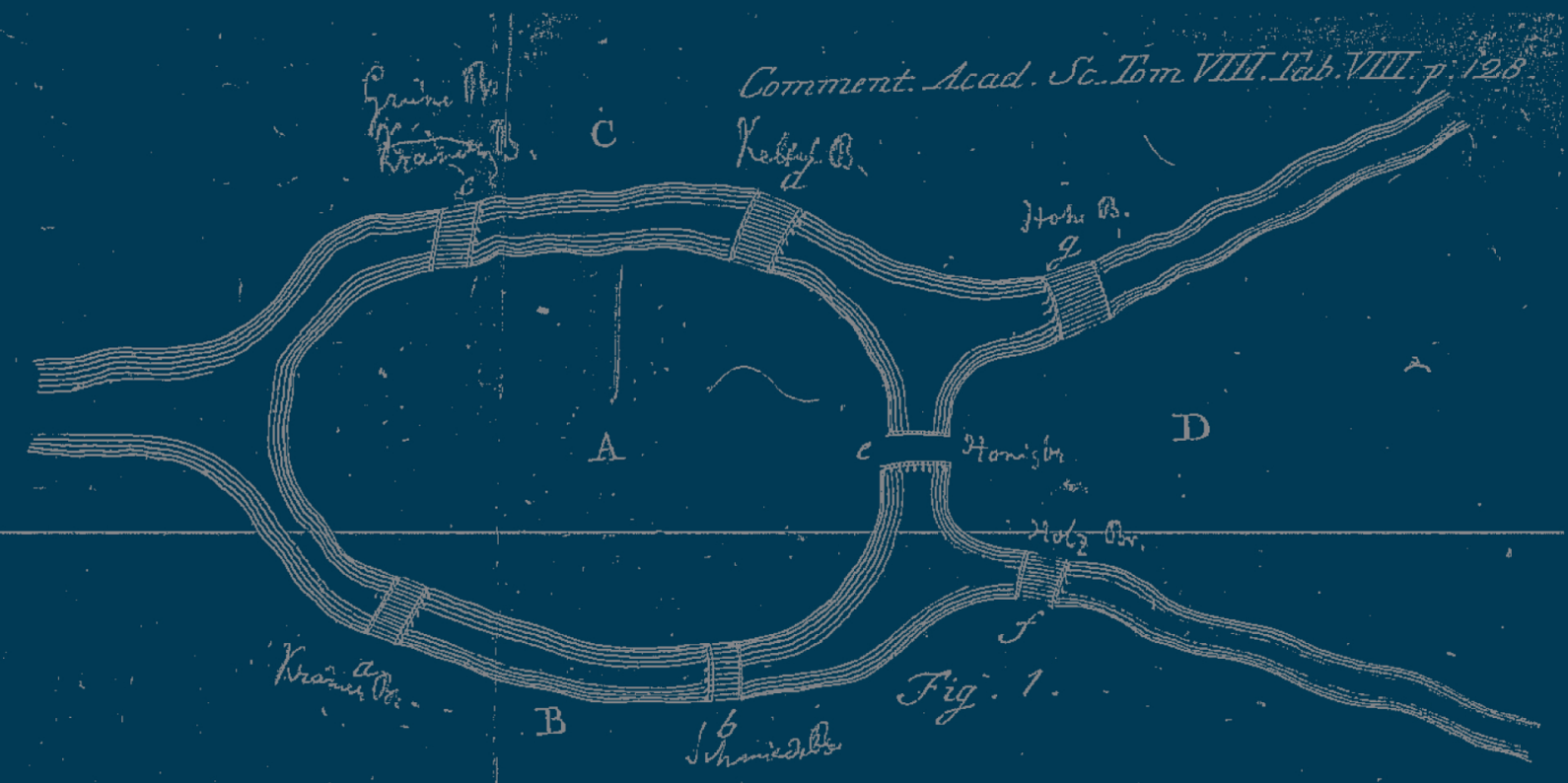

IMPRENSA DA

UNIVERSIDADE

DE COIMBRA

COIMBRA

UNIVERSITY

PRESS 
Chapter 15

CHARACTERISTICS AND CONSEQUENCES OF TEMPORAL ORIENTATION FOR PSYCHOLOGICAL WELL-BEING: LEARNING FROM THE PAST, FEARING THE FUTURE AND LIVING FOR TODAY

\author{
James M. Jones \\ Jordan B. Leitner \\ Charlotte Marshall \\ Yiming Jing \\ Jeong Min Lee \\ University of Delaware, USA \\ jmjones@psych.udel.edu
}

\begin{abstract}
AвSTRACT: Typically, past orientation predicts negative psychological outcomes and future orientation predicts positive psychological outcomes. However, orienting to the past need not always produce negative psychological outcomes. When the past is viewed from a positive hedonic frame, or a frame that lays a foundation of self-knowledge, self-awareness and collective belonging and pride, positive associations with the self are made. Conversely, if one's future focus is based in fear and worry, concern with a lack of control, then the psychological impact in the present may be much less positive. Study 1 demonstrated that Past-Self-Knowledge is positively, and Future-Worry is negatively related to psychological well being. Study 2 showed that death salience disrupted patterns of future and past time travel drawing people more closely to the present.
\end{abstract}

Keywords: temporal orientation, psychological well-being, terror management theory.

\title{
INTRODUCTION
}

The capacity for reflexive thought allows a person to consider his or her life over time. A person is defined by past experiences and how they are remembered, felt and interpreted, as well as expectations for the future and how vividly they influence ongoing judgments. Lewin's (1947) field theoretic approach held that the life span consisted of recollections of the past as well as visions of the future and that each was simultaneously accessible in the present. The self, then, is an integration of one's past and visions of the future in the present.

We regard temporal orientation as the tendency to focus attention on and react to the past, present, and future. Generally, we focus attention on the content and possible behaviors that convey positive feelings, and avoid those that are negative. Whether projecting oneself forward by considering possible selves or engaging in a life review, or engaging in expressive or defining behaviors from day to day, temporal regions are characterized by the image of the self found therein.

Research has generally shown that a past orientation or bias is associated with negative psychological outcomes and processes that precipitate and sustain them. Conversely, 
future orientation is associated with positive psychological outcomes like optimism, selfesteem, conscientiousness and processes that sustain them like impulse control, goal setting (Holman \& Silver, 1998; Zimbardo \& Boyd, 1999; Jones, Banisky \& Lasana, 2002).

However, orienting to the past need not always produce negative psychological outcomes. When people view the past from a positive hedonic frame, they tend to have higher self-esteem, lower anxiety, and depression, and are more energetic and friendly (Zimbardo \& Boyd, 1999). Conversely, future focus need not always leads to positive outcomes. If one's future focus is based in fear and worry, concern with a lack of control, then the psychological impact in the present may be much less positive.

Finally, the hedonic basis for a positive view of the past may be compared to a selfknowledge basis of a past focus. In the latter case, a past orientation lays a foundation of self-awareness and collective belonging and pride. This Past-Self-Knowledge view may also lead to positive psychological outcomes but may follow a different pathway.

The present studies assess these two new facets of past and future orientation. Study 1 tests the possibility that Future-Worry and Past-Self-Knowledge reverse the conventional relationships with psychological well-being found in the literature. Study 2 differentiates them from general measures of Past and Future orientation by manipulating mortality salience (Greenberg et al., 1990) as a means of foreshortening the future. We expect that mental or emotional "time-travel" (Arnold, McDermott \& Szpunar, 2011) will be truncated by this manipulation, but that the effects of Future-Worry and Past-Self-Knowledge will be largely unaffected. In fact, Future-worriers may actually be more prone to a future focus since mortality salience confirms the legitimacy of their worry.

\section{STUDY I}

\section{Method}

Ninety four introductory psychology students participated in exchange for partial course credit. Participants reported their Past, Present, and Future orientations on a conventional measure of temporal orientation (Jones et al., 2002). To assess Past-Self-Knowledge, participants responded to the Past-Self-Knowledge Scale, a 5-item scale that measures the degree to which one's past informs one's present and future (e.g., "To understand the present, I have to know the past"), on a (Agree Strongly) to 7 (Disagree Strongly) scale, $\alpha=.78$. Next, participants completed the Future-Worry Scale, a 5-item scale that measures the degree to which one worries about the future ("I often worry about what will happen to me in the future"), on a 1 (Agree Strongly) to 7 (Disagree Strongly) scale, $\alpha=.87$. Finally, participants completed the autonomy, environmental mastery, and self-acceptance dimensions of the Psychological Well-being Scale (Ryff \& Keyes, 1995), and self-esteem (Rosenberg, 1965), optimism (Scheier, Carver \& Bridges, 1994), satisfaction with life (Diener, Emmons, Larsen, \& Griffin, 1985), and affect scales (Watson \& Clark, 1994).

\section{Results and Discussion}

As shown in Table 1, Past orientation was unrelated to Present and Future orientation. However, Past-Self-Knowledge was positively related to Past, Present, and Future 
orientations, suggesting that greater Past-Self-Knowledge provides greater access to all temporal periods. Additionally, Future-Worry was unrelated to Future orientation.

Past orientation corresponded with lower PWB, and Future orientation corresponded with greater PWB. However, as hypothesized, Past-Self-Knowledge predicted greater PWB, and Future- Worry predicted diminished PWB.

Table 1 - Correlation coefficients

\begin{tabular}{|l|c|c|c|c|c|c|c|c|c|c|c|c|c|}
\hline & $\begin{array}{c}\text { TOS } \\
\text { Past }\end{array}$ & $\begin{array}{c}\text { TOS } \\
\text { Pres }\end{array}$ & $\begin{array}{c}\text { TOS } \\
\text { Fut }\end{array}$ & $\begin{array}{c}\text { Past-Self- } \\
\text { Know }\end{array}$ & $\begin{array}{c}\text { Fut- } \\
\text { Wor }\end{array}$ & $\begin{array}{c}\text { Self- } \\
\text { Est }\end{array}$ & Opt & $\begin{array}{c}\text { Auto- } \\
\text { nomy }\end{array}$ & $\begin{array}{c}\text { Eniv. } \\
\text { Mast. }\end{array}$ & $\begin{array}{c}\text { Self- } \\
\text { Acc. }\end{array}$ & $\begin{array}{c}\text { Pos. } \\
\text { Aff. }\end{array}$ & $\begin{array}{c}\text { Neg. } \\
\text { Aff. }\end{array}$ & SWL \\
\hline TOS Past & 1 & .07 & .09 & $.41^{* *}$ & $.54^{* *}$ & $-.46^{* *}$ & $-.39^{* *}$ & -.15 & $-.25^{*}$ & $-.19^{\dagger}$ & $-.22^{*}$ & $.32^{* *}$ & $-.31^{* *}$ \\
\hline TOS Pres & & 1 & -.00 & $.30^{* *}$ & -.01 & $.19^{\dagger}$ & $.26^{*}$ & .11 & 0.15 & $.31^{* *}$ & $.19^{\dagger}$ & $-.19^{\dagger}$ & .17 \\
\hline TOS Fut & & & 1 & $.25^{*}$ & .16 & $.26^{*}$ & $.28^{* *}$ & .11 & $.37^{* *}$ & $.21^{*}$ & $.38^{* *}$ & -.08 & $.23^{*}$ \\
\hline $\begin{array}{l}\text { Past-Self- } \\
\text { Know }\end{array}$ & & & & 1 & $.20^{\dagger}$ & .05 & .10 & .03 & .08 & $.20^{\dagger}$ & $.38^{* *}$ & $-.20^{\dagger}$ & $.19^{\dagger}$ \\
\hline Fut-Wor & & & & & 1 & $-.37^{* *}$ & $-.40^{* *}$ & $-.24^{*}$ & $-.24^{*}$ & -.16 & $-.22^{*}$ & .16 & -.08 \\
\hline
\end{tabular}

${ }^{\dagger} p<.10{ }^{*} p<.05^{* *} p<.01$

Study 1 thus demonstrated the viability of the Past-Self-Knowledge and FutureWorry as extensions of traditional models of temporal orientation. Correlations suggest that integrating the past into the present and future is beneficial for mental health, while excessive worrying about future events diminishes mental health. Study 2 extended these findings to test whether mortality salience moderates temporal orientation's relationships with mental "time-travel".

\section{STUdY 2}

\section{Method}

One-hundred eighty six introductory psychology students participated in an online one-way design (mortality salience vs. control) in exchange for partial course credit. First, participants completed all of the temporal orientation measures from Study 1. Participants then described the thoughts and emotions that death (or dental pain) evokes, and what they think will happen as they experience death (or dental pain). Next, to determine whether mortality salience affects the ability to mentally access the past, participants described their five most memorable memories. We operationalized memory elaboration as the total number of words participants used to describe their memories. Finally, participants described five goals for the future. To determine whether mortality salience affects the ability to access the future, participants indicated for each goal whether they agreed that they had "thought carefully about attaining this goal" on a 1 (Disagree Strongly) to 7 (Agree Strongly) scale. 


\section{Results and Discussion}

To test whether mortality salience truncates one's ability to access the past, and whether this tendency is moderated by Past orientation, we regressed the total number of memory description words on condition $(0=$ control; $1=$ =mortality salience), centered Past orientation, and the interaction in a regression model. The interaction was significant, $b=-33.92, S E=10.70, p=002$. Simple slope analyses revealed that greater Past orientation predicted greater memory elaboration in the control condition, $b=70.91, S E=21.97$, $p<.001$. In the mortality salience condition, however, Past orientation was unrelated to memory elaboration, suggesting that mortality salience limits "time-travel" to the past. Past Self-Knowledge was unrelated to memory elaboration in both experimental conditions.

To test whether mortality salience truncations one's ability to access the future, and whether this relationship is further moderated by Future orientation, we regressed goal concern on condition, centered Future orientation, and the interaction in a linear regression model. The interaction was significant, $b=.46, S E=.22, p=.04$. Simple slope analyses revealed that greater Future orientation predicted greater goal concern in the control condition, $b=.10, S E=.36, p<.01$. In the mortality salience condition, however, Future orientation was unrelated to goal concern. Future-Worry was unrelated to goal concern in both experimental conditions.

\section{General Discussion}

These studies demonstrate the dual effects of cognitive and affective processes on the temporal dimensions of the self. The consequences of focusing on the past or future depend on the affective orientation one holds. Past focus has negative effects on current psychological well-being if it is based in negative affect, but not if it is based in a constructive and valued view of the contemporary self. Conversely, future focus contributes positively to psychological well being when desired outcomes are expected and more confidently anticipated, but negatively when worry is the dominating affect with which the future is considered.

In our studies, death salience curtails time travel in both directions (past and future), but only for people who are respectively past and future oriented. Death salience disrupts well learned patterns of thinking about and reacting to the past or future. Past SelfKnowledge and Future-worry were unrelated to memory elaboration and goal concern, respectively, suggesting that these dimensions do not predict the frequency with which one cognizes about the past and future. Rather, these aspects of temporal orientation may determine whether past and future thoughts are integrated into the current self. These aspects of temporal orientation suggest the need for a more elaborate view of how focusing on temporal regions is influenced by the interaction of cognitive and affective factors.

\section{REFERENCES}

Arnold, K. M., McDermott, K. B., \& Szpunar, K. K. ( 2011) Individual differences in time perspective predict autonoetic experience. Consciousness and cognition: An international Journal, 20, 712-719. 
Diener, E., Emmons, R. A., Larsen, R. J., \& Griffin, S. (1985). The satisfaction with life scale. Journal of Personality Assessment, 49, 71-75.

Greenberg, J., Pyszczynski, T., Solomon, S., Rosenblatt, A., Veeder, M., Kirkland, S., \& Lyon, D. (1990). Evidence for terror management theory II: The effects of mortality salience on reactions to those who threaten or bolster the cultural worldview. Journal of Personality and Social Psychology, 58, 308-318.

Holman, E. A., \& Silver, R. C. (1998). Getting "stuck" in the past: Temporal orientation and coping with trauma. Journal of Personality and Social Psychology, 74, 1146-1163.

Jones, J. M., Banicky, L. \&. Lasane, T.P. (2002) A Temporal Orientation Scale: Focusing Attention on the Past, Present and Future. Unpublished manuscript. University of Delaware

LewIn, K. W. (1947) Field theory and learning. In D. Cartwright (Ed.), Field theory in social science: Selected theoretical papers. Westport, CT: Greenwood.

Rosenberg, M. (1965). Society and the adolescent self-image. Princeton, NJ: Princeton University Press.

RyfF, C., \& Keyes, C. (1995). The structure of psychological well-being revisited. Journal of Personality and Social Psychology, 69, 719-727.

Scheier, M. F., Carver, C. S., \& Bridges, M. W. (1994). Distinguishing optimism from neuroticism (and trait anxiety, self-mastery, and self-esteem): A re-evaluation of the Life Orientation Test. Journal of Personality and Social Psychology, 67, 1063-1078.

Watson, D., \& Clark, L.A. (1994). The PANAS-X: Manual for the Positive and Negative Affect Schedule-Expanded Form. Ames: The University of Iowa.

Zimbardo, P. G., \& Boyd, J. (1999). Putting time in perspective: A valid, reliable individualdifference metric. Journal of Personality and Social Psychology, 77, 1271-1288. 